\title{
CONCEPTUAL STUDENTS' PERCEPTION OF PROBLEM- BASED AND PROJECT-BASED LEARNING IN A HIGHER EDUCATION INSTITUTION
}

\author{
Ruta Meiste $^{1}$, Ausra Lankauskiene ${ }^{2}$, Iluta Arbidane ${ }^{3}$ \\ ${ }^{1}$ Dr. oec., associate professor, Utena University of Applied Sciences, Lithuania, \\ e-mail: rutameiste@gmail.com \\ ${ }^{2}$ Mg. paed., lecturer, Utena University of Applied Sciences, Lithuania, \\ e-mail: studijosvtf@utenos-kolegija.It \\ ${ }^{3}$ Dr.oec., associate professor, leading researcher, Rezekne Academy of Technologies, \\ Rezekne, Latvia, e-mail: Iluta.Arbidane@rta.lv
}

\begin{abstract}
The paper deals with conceptual students' perception of problem-based learning and project-based learning in a higher education institution. Nowadays students have a different lifestyle, various opportunities to study and different learning habits, so traditional learning does not satisfy them. Teachers must look for more modern ways to transfer the information and to explain the topics and issues. And some of these ways are problem-based learning and project-based learning methods. The authors of the paper carried out the research, assessing the students' point of view on these modern ways of learning. The research methods: literature analysis and comparative method, which allowed to clarify and to compare the differences of problem-based and project-based learning, and the questionnaire to get the students' opinion about these methods used in a higher education institution.
\end{abstract}

Keywords: problem-based learning, project-based learning, learning barriers, learning approach, students' perception.

JEL code: $M 12$.

\section{Introduction}

The relevance of the topic. The significance of higher education is increasing every year, attracting not only graduates looking for their own way, but also those who have graduated in the past and want to acquire a specialty, retrain themselves or change something in their lives. Such a great diversity of learners and their diverse needs make it necessary to combine education with the professional life, lifestyle, and financial opportunities. Therefore, traditional learning is complemented or replaced by various other teaching/learning methods. There is a need to conduct studies differently in a non-traditional way, to apply other forms and methods that are different from traditional teaching practice. Problem-based learning (PBL) is one of them.

The aim of this paper is to assess students' perception of problembased learning and to investigate its effect on the student's achievements. 


\section{Application of the Problem-Based Learning Approach in a Higher Education Institution}

Many education systems have investigated ways to improve student achievement in universities. Effective higher education institutions have high standards, intensive involvement and a willingness to experiment with a variety of strategies to improve education. Teachers are looking for more effective methods to make the subject easier adapted and interesting for students, as well as to teach them implement theoretical knowledge in practice. Therefore, the problem-based learning (PBL) strategy allows having higher standards in the academic area and joining a few different subjects that complement each other, dealing with the given task - problem to solve.

According to Savery (2006), problem-based learning is a studentcentred learning access that enables learners to conduct research, integrate theory and practice, and apply knowledge and skills to develop a viable solution to a defined problem (Fig.1).

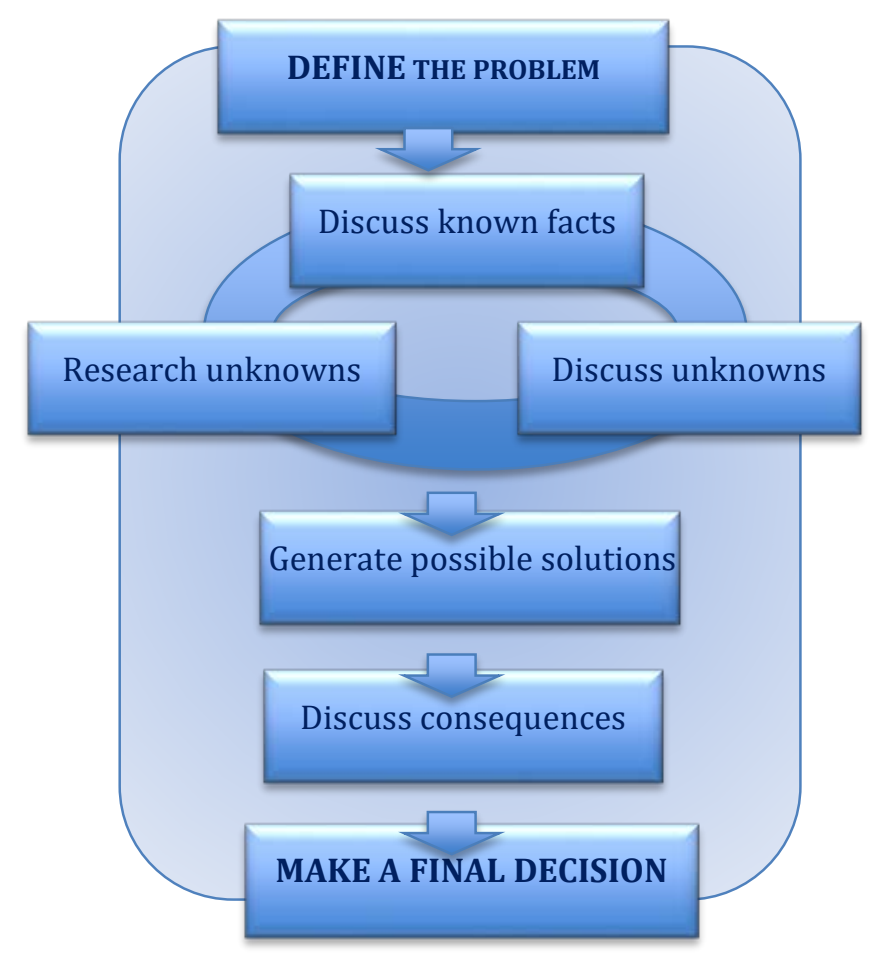

\section{Fig.1 Problem-Based Learning Performance Scheme}

(made by the authors)

Hmelo-Silver (2004) described problem-based learning (PBL) as a teaching/learning method that ensures that students, assisted by a teacher, learn to solve problems. The problem-based learning (PBL) method focuses on a problem without one correct answer. Importantly, PBL involves 
students working in groups to identify what they need to know to solve the problem. Students adapt their knowledge to solve the problem and reflect on their learning and the effectiveness of the strategies used. Torp and Sage (2002) have defined PBL as experience-based learning that focuses on research and the solution of difficult real-world problems. The authors see students as interested problem solvers who seek to identify the main problem and conditions necessary for good decision making. The goal of PBL is to find the best solution to the problem to be solved. At the same time, PBL includes the process of analysing the problem and its environment, activating knowledge and searching for information, teamwork, and finally finding a valuable solution (Zumbach, 2003). Thus, PBL is not identical to learning to solve problems. The learning process itself, not just the result the problem solved - has a fundamental value. Having analysed the definitions of different authors, it can be said that PBL is the way students study, analyse and solve complex real-world problems with the help of a teacher. PBL is a way to manage the growing content of professional knowledge, which allows developing the skills that will be applied to the professional activities of prospective professionals, no matter in which professional field they work. There is so much knowledge that it is impossible to master them as pre-given content, so the only way in the study process is not to provide the defined content, but to provide the right conditions for students to acquire and manage their knowledge.

PBL as a way to teach at a higher education institution was introduced in the field of biomedical learning in Canada (Barrows, 1999). Currently, PBL is applied in many countries for medical education. Over the last decade, PBL has become increasingly active, extending this strategy to various higher education study programmes (e.g. engineering, economics, social work, etc.)

Teaching the students of social and technological sciences is one of the most challenging tasks. The teaching instructions stress the importance and understanding, and the ability to apply scientific models to completely realize the key specifications in the learning subjects. Teachers must adapt instruction to the students' level of knowledge and development, motivate them to learn, and manage their learning skills. Instructions and learning should be effective.

Moving from traditional to problem-based learning can cause anxiety, even hostility. As Margetson (1997) points out, problem-based learning can lead to fear of change that will destroy the normal understanding of work, and the learning outcomes will not be clearly measured. The main hostility is based on the doubt that competences can develop from the discovery process. Students who are accustomed to traditional methods may feel frightened by changing and resisting the entire learning system. Students have difficulty working in groups and being active. It is also a challenge for 
teachers to carry out this type of training, to develop other access to material submission, task formation and evaluation system development.

Particular attention should be paid to PBL infrastructure. From large audiences, where students sit back and face their eyes at the teacher as the centre and the only source of knowledge and wisdom, the students move into PML discussion spaces, where they can freely and freely discuss in small groups of 6-8 at the round table. The organization of the study process by PBL provides for an appropriate allocation of student flows to small groups, enabling them to communicate within a separate round table, with independent learning resources and appropriate tutor support.

From the students' point of view, this approach to learning seems to create the impression that "theory" and "practice" are two different realms (Valentine, Speece, 2002), never touching each-other, and that what they learn at school and at university is "just" theory i.e. knowledge perceived as useless (Gross, Rutland, 2017) - possibly because it is "inert" (Meijering et al., 2016).

In fact, in the traditional approach to learning, classes are for knowledge, while the practical aspect is left to learning by doing. This foster somehow the idea that the two realms have nothing to do with each other. After analysing the aspects of problem-based learning, it can be said that problem-based learning does not provide clear evidence that it is superior to traditional studies. However, competencies developed through problembased learning make it a priority for higher education institutions.

Therefore, more and more innovative methods are being sought. And one of them is project-based learning (PrBL).

\section{Perception of the Project-Based Learning Approach in a Higher Education Institution}

Live projects within the role of Students' Consultancy have gained some attention in the last 3 years. They are a kind of active (Bonwell, Eison, 1991), experiential learning (Kolb et al., 2008; Holmberg et al., 2019), presenting particular features. The students, organised in small groups, act as consultants to a real life commissioner (business, business association, local government) for a real "live" problem or development opportunity that the commissioner needs to explore and achieve. The commissioner/business contact interacts directly with the group of students-consultants in terms of providing an appropriate brief for a new opportunity or analysis of an existing problem or issue as well as providing appropriate feedback.

However, team working, problem solving, communication, etc. are essential for employability (Trujillo, 2011; Kuh et al., 2008; Zhai et al., 2017; Fallows, Steven, 2000), especially in the service sector (Chang, 2014), and 
even more importantly within a managerial career (Bigelow, 1991; Carroll, 2005; Boyatzis, 1982; Zhang, 2017; Analoui, 2009; Holmberg et al., 2019).

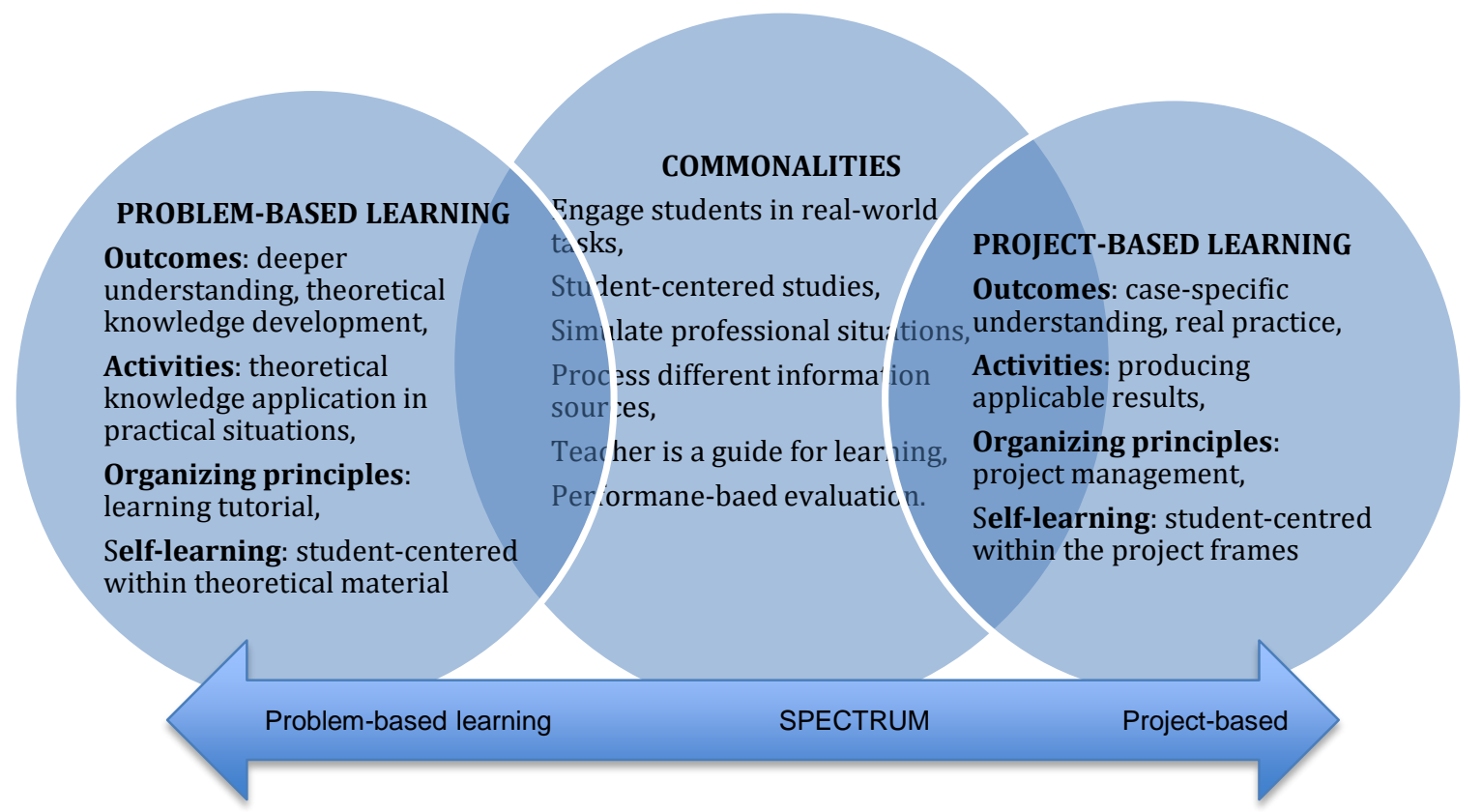
Fig.2 Differences and Similarities between Problem-Based Learning
and Project-Based Learning

(made by the authors)

Some of the key concepts and principles of live projects within the role of student consultancy are identified as follows:

- a focus upon the development of critical thinking and resolution of problems for today's dynamic managers,

- business clients offer their support (Holmberg et al., 2019; Garillos, 2012),

- $\quad$ an overlap of time between the experiential learning process of understanding the role of consultancy and undertaking the live project itself in a professional manner (Holmberg et al., 2019; Guido, 2014),

- $\quad$ an informal lecturing approach which focuses upon continuous encouragement, guidance and feedback,

- $\quad$ students identify with and act at all times within a professional capacity as actual external consultants,

- a share of tacit knowledge, transmitted by the lecturer and the commissioner by direct contact, behaviour imitation and shared experience,

- no separation of 'skills' from content, as the development of problem solving, organizational skills, communication, technical, 
etc. skills and critical thinking is not separated from the subject matter (Holmberg et al. 2019; Zulpiene, 2012),

- learning involves a student, a lecturer, and a commissioner (Holmberg et al., 2019).

\section{Research Methodology}

The challenge of this research study is the use of the problem teaching approach in subject materials and to investigate its effects on the student's achievement. This research study is focused on the educational research that builds the framework in the evaluation of the cognitive ability, behaviour and attitudes of the learners.

The aim of the research was to assess the effect of problem-based learning (PBL) on students' perception and to compare it with that of the project-based learning approach.

The research was carried out in spring 2019, questioned the target groups of students of Business Management and Transport Business study programmes, who experienced both methods in their study process. The PBL approach was applied in the Module Research and IT (10 ETC), which involves two subjects: Social Research (4 ETC) and Statistical Data Analysis and IT (6 ETC) and Tutorials, while the project-based learning approach was applied in the Module Management of Trade and Service (12 ETC), which involves three subjects: Management of Trade and Service Enterprises (4 ETC), Marketing of Trade and Services (4 ETC), International Trade Funding (4 ETC) and Tutorials. In the first module, the problem-based learning approach is applied and in the second module - the project-based learning approach is applied, so the students can evaluate and compare these two learning methods, pointing out their efficiency, advantages and disadvantages. For this evaluation, a questionnaire was formed, which included 3 blocks of questions, emphasizing the described criteria of the both methods. The first block assessed barriers in the study process. The students evaluated 8 barriers, which made them difficulties in the learning process. The second block of questions estimated the advantages of these learning methods according to their importance and impact on the study process. The third block defined 8 main disadvantages and difficulties, which students faced in their learning process and discussed criteria influence on the students' learning efficiency. 


\section{The Results of the Research on Conceptual Students' Perception of Problem-Based and Project-Based Learning in a Higher Education Institution}

The first block of the questionnaire identifies the barriers, with which students were faced while studying the modules. They pointed out the biggest barrier, which appeared as the biggest gap, comparing these two learning approaches, too - teachers' poor preparation. Teachers' preparation is the key point in the problem-based learning process. The teacher's role in applying this method is not only to provide information and resources but to let students make decisions themselves on what to look for and what to learn. The teacher must control the process itself and evaluate process productivity.

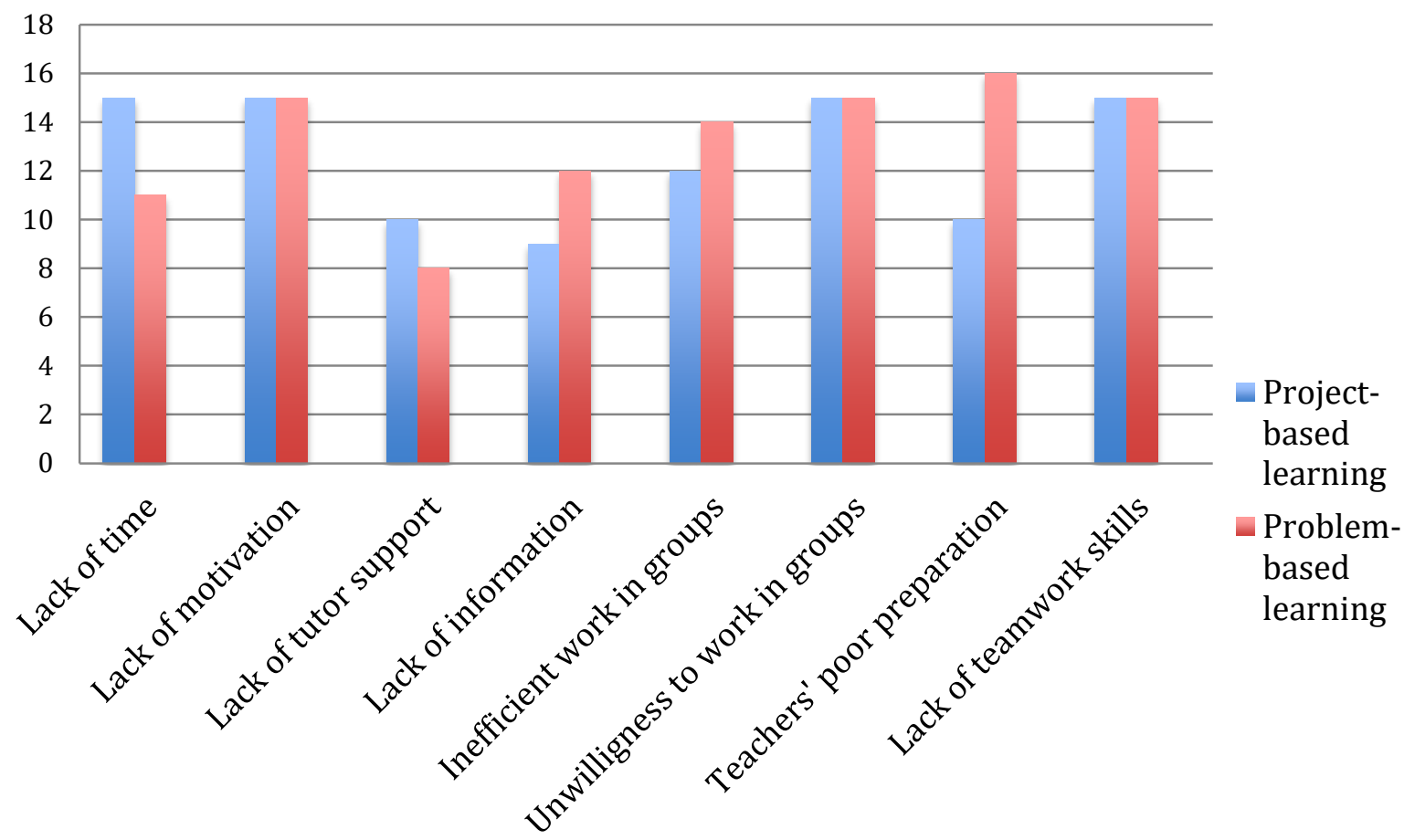

Fig.3 Student Perception about Learning Barriers (made by the authors)

However, the students pointed out teachers' poor preparation for the problem-based learning process, which disappears in the project-based learning process, where the problem is formed by the business people and the teacher's role becomes passive (see Fig.3).

The other barriers were defined as a lack of motivation, unwillingness to work in groups and a lack of teamwork skills, but these barriers are similar in both learning approaches.

Evaluating barriers in project-based learning, the students emphasized a lack of time as the biggest problem. The project-based learning approach 
consumes lots of time making projects. It takes much more time than in the problem-learning process.

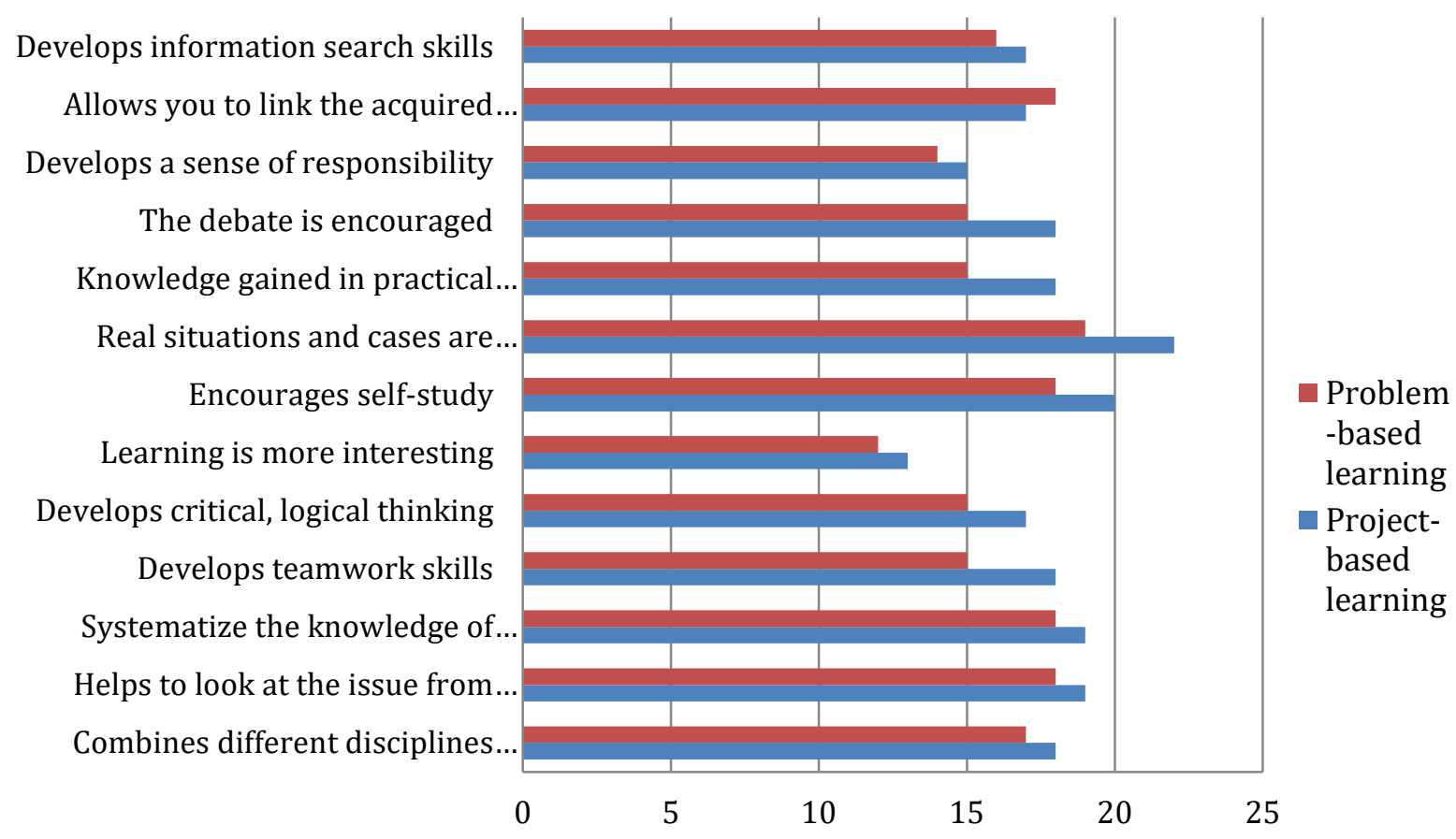

Fig.4 Student Perception of Learning Advantages

(made by the authors)

Analysing the advantages of both methods, it is claimed that though the students identified a lack of motivation to work in groups, but at the same time they acknowledged that both methods developed teamwork skills, encouraged self-studies, encouraged debates, developed critical and logical thinking (see Fig. 4). The biggest advantages of both methods were the fact that real situations and cases were analysed. The students could touch the real situations in a company, being faced with the real decision-making process after having analysed all the alternatives in the given situation. And also, it was very important that they could deal with the problem or situation from different perspectives and that it combined different disciplines.

Though the students identified a lot of advantages of both methods, still they found many disadvantages as well (see Fig. 5). In project-based learning, the biggest disadvantage was that it consumed a lot of time. You need to work hard, looking for information, conducting the research, collecting the needed information, and finding solutions. The other disadvantages in the projectbased learning process were too much self-studies and self-work and sometimes too difficult problems to be analysed. In problem-based learning, the students identified the tutor's focus only on the subject s/he taught and also they told that it took too much time, too much self-study in preparation for the lectures, etc. 


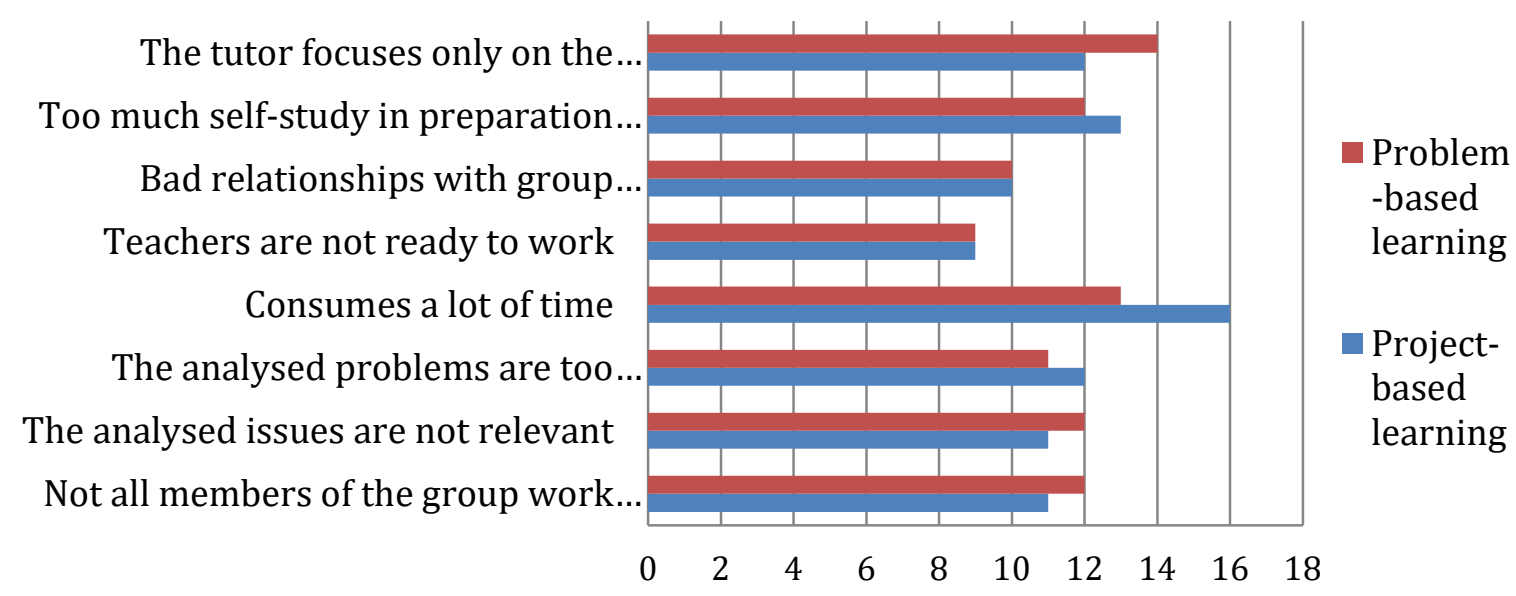

Fig.5 Student Perception about Learning Disadvantages

(made by the authors)

Having compared all the disadvantages of the discussed methods, it can be claimed that there is no big difference between them, the results appeared almost the same, discussing the negative points. The biggest difference was that project-based learning consumed even more time than problem-based learning, though it also required a lot of them and independent work. And the other difference was that in problem-based learning, a tutor focused only on the subject s/he taught. This problem vanishes in project-based learning when the tutor's role becomes not so relevant.

\section{Conclusions}

The findings of the research study show that the problem-based learning method in social sciences is not very effective for students' knowledge adaptation. But the survey revealed that the problem-based learning approach was very valuable to make students work in teams, to analyse all alternatives when making a final decision.

Both methods - problem-based and project-based learning have learning barriers, advantages and disadvantages. There is no big difference assessing them, but still some dissimilarities appeared: the biggest barrier in problem-based learning was the teacher's poor preparation, while in projectbased learning the students referred to a lack of time and motivation and unwillingness to work in teams. Considering the advantages of both methods, the students' pointed out the same quality that the real situations were analysed. On the other hand, the disadvantages were not identified the same: in problem-based learning, it was the tutor's focus only on the subject s/he taught, while in project-based learning, the students emphasized the lack of time, because this method required much time to perform all the necessary tasks. 
Therefore, the problem-based method would be more effective among the students students of Business Management and Transport Business study programmes, if the teacher were prepared better and were ready to apply it in their lectures and motivate students to deal with the problems.

\section{References}

1. Analoui, F. (2009). Challenges of successful reform: an international perspective. Journal of Management Development, Vol. 28 Iss.: 6, pp.489494, https://doi.org/10.1108/02621710910959648.

2. Barrows, H.S. (2016). The Application of Problem Based Learning in Undergraduate Nursing Education: A Strategy for Curriculum Reform. Journal of Biosciences and Medicines, Vol.4, No.6, June 30, 2016.

3. Bigelow, J.D. (1991). Managerial Skills Development, Thousands Oaks. CA: Sage.

4. Bonwel, C.C., Eison, J.A. (1991). Active Learning: Creating Excitement in the Clasrom.191ASHE-ERICHigherEducation Reports.

5. Boyatzis, R.E. (1982). The competent manager. New York, NY.: John Wiley \& Sons.

6. Carroll, C. (2005). Assessing Project-based Learning: a Case Study of an UnDergraduate Selling and Sales Management Module at the University of Li-Merick. In: Handbook of Enquiry and Problem-based Learning: Irish Case Studies and International Perspectives. Barret, T., Mac Labhrainn, I., Fallon, H. (eds.). AISHE Readings: CELT, NUI Galway, 2, pp. 94-104.

7. Chang, Y. (2014). Reorganization and plastic changes of the human brain associated with skill learning and expertise. Frontiers in Human Neuroscience, 8, $35 \mathrm{p}$.

8. Fallows, S., Steven, C. (2000). Building employability skills into the higher education curriculum: A university-wide initiative. Education and Training, 42, pp.75-83. doi:10.1108/00400910010331620.

9. Garillos, M.N. (2012). Development and Validation of Instructional Module in Biology for Second Year High School. TVC-Sta. Teresa National High School. 2012.

10. Gross, Z., Rutland, S. (2017). Experiential learning in informal educational settings. International Review of Education, 63, pp.1-8. doi:10.1007/s11159-0179625-6.

11. Guido, R.M. (2014). Evaluation of a Modular Teaching Approach in Materials Science and Engineering. American Journal of Educational Research, Vol. 2, No. 11, pp.11261130. Retrieved from http://pubs.sciepub.com/education/2/11/20.

12. Hmelo-Silver, C.E. (2004). Problem-based learning: What and how do students learn? Educational Psychology Review, Vol. 16(3). pp. 235-266.

13. Holmberg, E. (2019). Students' Consultancy. An International Perspective. A Guidebook for operating, implementing and managing students' consultancy live projects. 2019.

14. Kolb, A., Y., Kolb, D., A. (2008). Experiential learning theory: A dynamic, holistic approach to management learning, education and development. In S. Amstrong and C. Fukami (Eds.), The Sage handbook of management learning, education and development, London: Sage, pp. 42-68.

15. Kuh, G. D., O'Donnell, K. (2008). Excerpt from high-impact educational practices: What they are, who has access to them, and why they matter. Washington, DC: Association of American Colleges and Universities. 
16. Meijering, L.; Weitkamp, G. (2016). Numbers and narratives: Developing a mixedmethods approach to understand mobility in later life. Social Science \& Medicine, 168, pp.200-206.

17. Margeston, D. (1997). Why is Problem-based Learning a Challenge? In: D. Boud, and G. Feletti. The Challenge of Problem-based Learning. London: Kogan Page.

18. Savery, J.R. (2006). Overview of Problem-Based Learning: Definitions and Distinctions // The Interdisciplinary Journal of Problem-Based Learning. Vol. 1, No. 1. pp.9-20.

19. Torp L., Sage, S. (2002). Problems as Possibilities: Problem-Based Learning for K-16 Education // Alexandria, VA: Association for Supervision and Curriculum Development, 2002.

20. Trujillo, D. (2011). Peer-Assessment and group-composition in PBL: a case study. In: PBL across the disciplines: research into best practice. Proceedings from the 3rd International Research Symposium on PBL, Coventry University. Davies, J., Graaff, E., Kolmos, A. (eds). Aalborg University Press, pp. 568-581.

21. Valentine, D., Speece, M. (2002). Experiential learning methods in Asian cultures: A Singapore case study. Business Communication Quarterly, 65, pp.106-116. doi:10.1177/108056990206500314.

22. Zhang, J. (2017). Research ethics and ethical research: Some observations from the Global South. Journal of Geography in Higher Education, 41, pp.147-154.

23. Zhai, X., Liu, H., Gu, J., Lian, J.,C. (2017). An experiential learning perspective on students' satisfaction model in a flipped classroom context. Journal of Educational Technology \& Society, 20, 198-210. doi: https://jstor.org/stable/ jeductechsoci.20.1.198.

24. Zumbach, J. (2003). Problembasiertes Lernen. Munster: Waxmann.

25. Zulpiene, J. (2012). Modular Teaching in Comprehensive Schools: Didactic Teachers Preparation. Vytauto didžiojo universitetas, Magistro baigiamasis darbas, Švietimo vadybos studijų programa, valstybinis kodas 621X20021, Edukologijos studijų kryptis. 